\title{
Tautuaileva:
}

\section{A Samoan Hermeneutic to explore Egalitarianism in the Bible}

Vaitusi Nofoaiga, Malua Theological College

\begin{abstract}
The continuous changing of cultures and of the ways people think about the world brought about a new change in the world of hermeneutics (ways of interpreting a text). Martin Heidegger and Hans-Georg Gadamer brought into hermeneutics the significance of recognising the contemporary issues, social status and location of readers (Jasper 2004: 104-106; Thiselton 1980: 24-47). This brought about a shift from the classical hermeneutical approach to the structuralist, humanistic and critical approaches. In other words, in contrast to the traditional approach of interpretation that focuses on the author, biblical interpretation now considers the world of the reader, which brings a new dimension. It recognizes that each person brings his/her own questions to the text, and thus shapes his/her interpretation of the text. This is not to give the reader the opportunity to impose his/her meaning on the text, but to recognize what the reader brings from his/her contemporary situation and takes back to that situation. Our people (Samoans) as Christians believe that we find in the Bible answers to any question about living life in this world. This article is an attempt by a Samoan reader of the Bible to develop a Samoan hermeneutical critical approach that recognizes questions on some local issues in our Samoan world, to be used as a reading approach to seek in the Bible answers to those questions. The issue that raises questions for the hermeneutic explained herein is the issue of egalitarianism in relation to gendering and elitism in our contemporary Samoan society. The hermeneutical critical approach is called Tautuaileva and how it is used in reading a Bible text will be shown in an interpretation of John 4:16-30. Elaboration on how this reading approach is used in interpreting the Bible, see Nofoaiga 2017. Another example of reading the Bible from the Samoan perspectives, see Nofoaiga 2018.
\end{abstract}

Keywords: Tautuaileva, hermeneutic, egalitarianism, hybridity

\section{Introduction}

The Samoan hermeneutic, Tautuaileva, emerged from my experience and understanding of the issues of gendering and elitism in contemporary Samoan society. It is recognition of egalitarian issues in my Samoan world to be used as a guide in the search for more understanding of egalitarianism in the Bible. Thus, Tautuaileva identifies and recognizes the voice of the 'other' that is suppressed by gendering and elitism in a text. Gendering is a tradition or a belief functioning in a society (a society dominated by men), which defines and shapes how women and men should act and behave (Wainwright 1991: 28). It functions hierarchically within the patriarchal tradition. Elitism is, "advocacy of or reliance on the leadership or dominance of a select group," (Brown 1993: 800) and is recognized and respected phenomenon of power and knowledge that controls a society or community. Most societies took on a particular flavour of gendering and elitism as social, political and religious processes that represent colonialism. Thus, the gendering and elitism should be understood as colonial values. There were many ways used to introduce such colonial influential values in Samoa such as the Scriptures that were used as instruments and how this was possible has been demonstrated by Elaine Mary Wainwright and Malama Meleisea. Wainwright (1991: 2) writes in relation to the function of the scripture:

It became clear that while scriptures provided legitimation for the liberation of all who suffered under oppression, they were also used by many within the Christian churches as a weapon against the poor and marginalized, as a means of "keeping them in their place." 
Meleisea (1987: 52-59; 67-69), a Samoan historian, said that the new foreign ways such as the London Missionary Society's (LMS) teachings of the Bible brought a change that would benefit and improve the lifestyle of the Samoan people but beside many good results of the missionaries' work there were some failures, especially in transforming the traditional and cultural values of the Samoans. For example, traditionally, the women shared with men chiefly and priestly roles. The gendering the missionaries introduced which emphasized the woman's wifely role, nullified the traditional roles of a Samoan woman. From a Samoan biblical interpreter's point of view, I agree with Meleisea. The gendering understanding brought in by the first teachings of the missionaries was based on the one-truth ideology of men as the only chosen disciples of Jesus in Jesus' ministry. This type of gendering contradicts the shared-egalitarian responsibilities emphasized in the undertaking of the reciprocal and relational role of tautua in the male-female relationship in the Fa'aSamoa (Samoan culture), as practiced in the sister-brother relationship in the Samoan social and cultural world. Thus, the Samoan hermeneutic of Tautuaileva explained herein is shaped by the practice of the social and cultural egalitarianism in the culture of tautua in my Samoa world.

\section{The Samoan hermeneutic, Tautuaileva (serve/service/servant in between spaces)}

Tautuaileva as a hermeneutic considers my own location as a reader of the Bible in the Samoan world. I regard this location, a location in hybridity (a postcolonial approach), in which I place myself as a Samoan reader of the Bible. Mosese Mailo, a Samoan biblical scholar in his study of Bible translation in Samoan in the nineteenth century, emphasizes the use of postcolonial approaches (focusing on decolonization and emancipation) to investigate ideologies behind Bible translation (Mailo 2016: 263265). Mailo's study investigates how the colonial thinking of the missionaries influenced Bible translation in Samoan in the nineteenth century. My use of postcolonial approaches as shown herein is different. They are used as hermeneutical approaches to situate my location as a reader of the Bible in today's world.

Hybridity according to Homi Bhabha is an intervening space (Bhabha 1994: 163), which is not a new horizon but a location he calls "beyond" (Bhabha 1994: 1-2, 121-131, 145-174; Ashcroft, et al. 139). In this sense, hybridity is a new space or the third space, which gives any person an opportunity to explore the Bible and any space or place beyond the norms of the past and the present. I claim egalitarianism as the critical element of my being in that third space to identify and expose the 'local people in need' in the Bible and in local Samoan communities. This is important because as Ricouer suggests, we cannot fuse two horizons neatly, such as the horizon of the text and the horizon of the reader of the text. A critical element is needed to make more sense and more interesting an exploration of an issue in between horizons (Lundin 1985: 26-27; Habermas 1985: 293-219; Warnke 1987: 129-132).

The consideration of egalitarianism as the critical element for my hermeneutic comes from my experience with the struggle faced by some of our local people's (poor and marginalized) vying for equal opportunities and egalitarian access to local resources. For example is the current issue of the Government's proposed amendment Bills, the Land and Title Court Bill and the Judicature Bill. The proposed changes would see the Land and Titles Court have its own High Court and Court of Final Appeal and Review. This is a significant change to the current system where the Supreme Court is the court of appeals. Could this be a change that would affect mostly the poor and the marginalized in families and villages in Samoan society? Thus, what equality or egalitarianism means to us as local people in our local Samoan values and cultures should be the basis for any hermeneutical approach we attempt to construct to guide any exploration or examination of any issue in our Samoan society. We should not rely solely on what equality or egalitarianism means as proposed by the world chart of human rights for it does not do justice for the local Samoan society with customs, values, and traditions that are not so rigidly defined. Rather, the hermeneutic presented here presents my own understanding of egalitarianism from my perspective of a tautua (servant) in a local family and church within a Samoan society. The Tautuaileva hermeneutic will be explained in these sections. First, how my being a tautua expresses and depicts my sense of place as a member of a local Samoan family and 
church. The significance of place determines how and why l enter the third space, Tautuaileva. Second, entrance into this third space conveys my understanding of egalitarianism followed by the consideration of egalitarianism as the critical element of this hermeneutic in the third section. Fourth, from this understanding evokes the categories of Tautuaileva to be used as lenses to explore egalitarianism in any biblical text such as the text interpreted herein - John 4:16-30.

\section{Tautua my sense of place}

According to Charles Taylor (1985: 129) "we cannot understand another society until we have understood ourselves better as well." For me, in order to understand undertaking service as an egalitarian shared role that aims to help those in need, I have to understand the culture of service (tautua) in my world as a Samoan. Tautua as a concept has two significant meanings (Tofaeono 2000: 300). First it identifies the servant status and role of untitled men in the Samoan chiefly system. Second, it expresses the moral value of serving the family. Thus, tautua as the culture of service in Samoa is a family-based social and cultural status, role, value, and practice, which views the needs, rights, and roles of people in the family and community as primary. Being immersed within and through that culture, I consider myself a tautua. It is the fatuaiga tausi (role of a member of the family) of any member of a Samoan family regardless of status and gender. Thus, the fundamental existence of tautua begins within the family. Tautua in terms of belonging to a family, village, and church, including chiefly title appointments, is expressed in Samoan as $f a^{\prime}$ asinomaga. There is a saying in Samoan, 'O le tagata ma lona fa'asinomaga' (The person and his or her sense of identity). It expresses the connection a person has to a particular family or who the person is in terms of the family he/she comes from. The word fa'asinomaga is made up of two parts, fa'asino and maga. Fa'asino, is a verb meaning 'point,' or 'direct', which points a Samoan to a particular family and village that he or she belongs or is linked to (Milner 1966: 50). The particular families and villages that a tautua belongs to, have title names, customary lands, and residential places particular to themselves. The second part, maga, is a suffix (Milner 1966:120) that makes fa'asino a noun, fa'asinomaga. Thus, fa'asinomaga is a way of identifying a tautua in and through his or her social and cultural links to a Samoan family and village in Samoan society. Part of a tautua's fa'asinomaga is that it points a tautua to his social and cultural status and role.

Fa'asinomaga (sense of belonging to a place) of a tautua also points a tautua to particular relationships he belongs to within his family and certain roles he is to carry out to fulfil being part of those relationships. Examples of those relationships are the tautua's relationship to the matai (Samoan chief) and to his sisters (Schoeffel 1995: 85-105; Le Tagaloa 1997: 16-20). Carrying out his role in those relationships is demonstrated by the Samoan word va fealoa'i. $V a$ is a noun meaning space, any space. Not just spaces between people but metaphorical spaces between people and social, cultural, and religious systems in a particular place. This space is relational. The word fealoa'i means to interact respectfully. Thus, va fealoa'i designates any type of relationship such as relationships inbetween people, and between people and the social and cultural systems that function in that society. So, a tautua is expected to relate to other people and spaces with respect.

These spaces are relational and have boundaries and are described in Samoan as tuaoi. Tuaoi is the short form of the Samoan phrase 'tua atu o i' which means 'beyond this point' (Ta'isi Efi 2008). It expresses the expectation that respect for other people, owned lands such as customary lands, statuses such as social and cultural status in the chiefly system and relationships such as the chieftautua relationship is expected. The important function of these tuaoi is not to mark a dualism between the person in high status as the colonizer and the person in the low status as the colonized. Rather, the boundaries reveal the importance of the social and cultural order in a local Samoan family and community where the young people respect the elders or the untitled men and women respect any person chosen by the family as family leader. What this means is that sometimes families select to be a leader someone young whom they see to have the wisdom or has already proven in and through his serving the family that he or she is the good person to lead the family. It is not that other people who are older than him are not good enough but it is a decision everyone in the family agrees is good for the family. A tautua's sense of place as fa'asinomaga concerns how he is linked to his family 
and the space which his family inhabits within a village. Part of that $f a^{\prime}$ asinomaga is the relationships to which he belongs and his role in those relationships.

\section{Tautuaileva (service in-between spaces): My location in third space}

Tautuaileva is the word I have coined as short form of the Samoan phrase 'tautua i le va.' This phrase means a service that is carried out in-between spaces or a servant standing in-between spaces. It expresses the expectation that the role of undertaking a service within a family or community is a reciprocal responsibility where the needs and rights of everyone are important. My utilization of Tautuaileva as one word has significance. It shows that my hybrid location as that of a third space - in between my understanding of service in Samoan and Christian cultures - has no gaps in between. As such, it reveals that in times of undertaking my service role to both my family and church units, I negotiate and renegotiate the fulfilment of my needs and roles in relation to both units, depending on which unit's needs are given priority. It is the location where I stand as a servant allowing myself to accept changes and challenges in life and choosing what change and challenge is relevant or mixing them in a way that would help fulfill my role and responsibility to both my family and church. As such, tautua is no longer restricted to a particular level, space, culture, and people. It shows that a tautua needs courage to face challenges and changes in today's world such as the courage to break away from the expectations considered as traditions in his or her place of belonging and to seek in other spaces other ways that will improve his or her tautua. Thus, my location in the third space, Tautuaileva, is a dynamic location where I move to and from space to space as a tautua, and act in accordance with the reality of life I encounter in my everyday life as a Samoan. This is where I stand as a Samoan and from which I see life in today's world. I claim egalitarianism as the critical element of my being in that third space in order to identify and expose the local people in need in the texts, and local places in Samoa. That egalitarianism will be defined in the next section.

\section{Egalitarianism: the critical element of my location in third space}

There are many types of egalitarianism. In this section, I explain the type emphasized in my location in the third space. I begin by defining the complex idea of egalitarianism. Because there is not only one type of equality, the following section includes examples of some types of egalitarianism leading to the version emphasized here. The Oxford English Dictionary defines egalitarianism as a belief in the natural "equality of mankind." It explains egalitarianism simply as equality. It has been the main thinking behind some major movements in history which have fought for equal treatment and rights. For example Roth (1995: 249-50) writes,

[i]n the twentieth century, egalitarianism has influenced movements for civil rights, women's rights, and equal opportunities for the disabled, and has promoted the idea that equality is an important moral principle.

While egalitarianism as equality seems like a straightforward matter, in reality, it is in fact far more complex. From a political point of view, Choi says that one reason why that complexity occurs is because egalitarianism as "equality is an intrinsically comparative idea" (Choi 2010: 411-414). She adds that comparing two things as equal is not an easy task unless particular aspects of each object thought to be equal are well specified. So egalitarianism as an idea to define and explain how people in different situations in a context relate to each other is a complicated and provocative exercise. For example, if I talk about egalitarianism from a poor person's point of view in a lower socio-economic situation, a rich person in a higher socio-economic bracket may see it differently. Thus, egalitarianism as a comparative idea shows that there is not one type.

As an example, Susan Kent has established a cross-cultural allocation of types of egalitarianism by comparing gender relations in society. She classifies egalitarianism into six types. I will mention only three to give an example of that comparison. These are: "[h]ighly egalitarian, [s]trongly egalitarian, [m]oderately egalitarian" societies and cultures (Kent 1999: 37). According to Kent, highly egalitarian 
societies are where gender relations are correlated. In such cultures, there are few societal differences between males and females. Both males and females equally make decisions for the group. The egalitarian societies Kent calls the strongly egalitarian are those where gender differentiation occurs but not in a hierarchical way. In such societies, males and females complement each other's existence. Kent's third type, the moderately egalitarian, defines societies where males and females complement each other in accordance with the hierarchical structure of that society. For Kent, there are clearly different types of egalitarianism once the issue of gender equality is raised. In her classification, there is no such thing as a purely egalitarian society.

Egalitarianism is also an important and contentious topic in Christian ethics and biblical studies. As a Christian ethic, egalitarianism is proposed by the following Christian teachings:

[egalitarianism is shown in] the creation of all men and women in God's image (Gen. 1:27), in the fall of all humans into sin (Rom. 3:23), and in God's love for all the world that resulted in Christ's death on the cross (John 3:16) (Essenburg 1992).

These teachings present egalitarianism as a general biblical and theological understanding. However, in studying Jesus' movements in Matthew's gospel, Dennis Duling warns about the use of egalitarianism because it has a limited quality (Duling 2011: 151-152). He refers to peasant egalitarianism in the first century Mediterranean world. He observes that that egalitarianism does not mention women explicitly because women do not challenge it. Duling's warning reflects the complexity of egalitarianism mentioned above by Choi which occurs when considering one meaning of equality to define egalitarianism for all people involved. From a feminist perspective, Wainwright sees equality and hence egalitarianism as a contentious term because it depends on who defines it; it is generally taken to mean 'equal' to the dominant power. She utilizes the concept of 'inclusion' instead of 'equality' by making a clear distinction between "inclusion" and "equality." She chooses to employ:

the principle of "inclusion" rather than "equality" as a necessary correlative to "liberation" since "equality" can function to hide the distinctive experiences of women and men or the distinctive qualities of those experiences in an attempt to show both that the same experiences have been or should be available to both (Wainwright 1991: 32).

Of course, there is no explanation of egalitarianism that can define or explain equality for all, for many contextual considerations must be taken into account. As a result, in this study, egalitarianism is defined and used relative to a particular area or context of life.

The type of egalitarianism emphasized in Tautuaileva hermeneutic is seen in Kent's description of moderately egalitarian societies in which males and females complement each other but in accordance with the hierarchical structure of society. It is non-gendered and non-elitist and is embedded in the reciprocal respect for each other in tautua - it is men and women filling different but complementary roles. This type of egalitarianism consciously has in its meaning the Christian values of servanthood as proclaimed and practiced by Jesus in his proclamation of God's kingdom, and Samoan social and cultural values of tautua. It is morally, ethically, and practically based signifying chosenness not as a comparative factor of inequality but equality as revealed in the sister-brother relationship and matai-tautua relationship in Samoan culture. It is about respecting those of high status such as elders and in return those in high status should earn that respect by being good leaders. Such leadership is considered their tautua. Also important in that type of egalitarianism is the ability of those in any hierarchy to have wisdom to decide which need in that hierarchy is to be given priority. In this way, enacting tautua is responding to help the person in need in accordance with the situation he or she is involved in. Thus, the egalitarianism emphasized in my third space location supposes that being chosen for a higher status is not an excuse to oppress those of lower status. Instead, it should 
make every person involved in a hierarchy undertake his or her role as tautua in relation to the needs and rights of all people involved.

\section{Categories of Tautuaileva as the hermeneutical lenses}

As mentioned above, my location in this third space of 'service in-between spaces' as determined by my sense of identity in relation to place in Samoa is not static. It is dynamic and liable to changes and challenges. It is open to changes from time to time and space to space according to changes and situations occurring in particular places. As such, it exposes the marginalized in my world and in the text. It shows that anyone is a tautua regardless of gender, status, color, and race. Accordingly, the following categories of my location in third space, Tautuaileva (service in-between spaces), are the lenses through which I seek to explore egalitarianism in the Bible: fa'asinomaga (sense of belonging to a place) and tautuatoa (courageous servant).

\section{Fa'asinomaga: Sense of belonging to a place}

As explained above, fa'asinomaga (sense of belonging to a place) is a way of identifying a tautua in and through his or her social, cultural, religious, political and economic links to a family and village in Samoan society. Fa'asinomaga in my third space location is open to new changes and challenges. Therefore who I am as a Samoan is sometimes identified and defined beyond the social and cultural restrictions of the norms of traditions my family and church have been practicing. In this way, fa'asinomaga of a tautua can be extended to other spaces and places forming and shaping new $f a$ 'asinomaga for the sake of making sense of belonging to another place. It is where a tautua is able to adapt his or her being Samoan to a new land, home, people, culture, language, and relationships, in order to make that place his or her own home. It is where a Samoan sees and views the world in light of the variety and diversity of cultures that run and control the locality of the world he or she inhabits. This allows the undertaking of tautua roles to go beyond the boundaries of the community and family-based original fa'asinomaga by seeking new fa'asinomaga that would help improve one's service roles to his or her family.

I have also explained that another part of fa'asinomaga faatautua (tautua's sense of belonging) is the relationships ( $v a$ fealoa'i) he or she belongs to which are not just relationships to people but to the social, cultural and religious systems in the place he or she inhabits. Thus, there are three functions of va fealoa'i from my third space location. First, va fealoa'i designates various relationships between people. Second, va fealoa'i expresses people's relationships to systems that run and control the local spaces they inhabit. Third, $v a$ fealoa'i is not just a response in silence to another person or other people but making one's voice heard either in or through words or actions. Thus, identifying and defining va fealoa'i is in accordance with the locality of the fa'asinomaga of those in need, and those who help fulfill those needs. More importantly, the tautua's sense of belonging to place enables him or her to identify the problem/s that marginalized him or her as tautua.

\section{Tautuatoa: Courageous servant}

Toa as a word added to tautua means bravery or courage. It makes tautuatoa a category that depicts a tautua who is able to go beyond the spaces he or she is familiar with to seek in other spaces ways to improve his or her role as tautua. As mentioned previously, the pathway to see, feel, and listen to how other's inhabit of the places they belong to is 'egalitarianism.' And this pathway is an action-inprogress. What this means is that this pathway is where a tautua is prepared to face challenges and changes choosing what is relevant to his or her tautua role and considers all needs important, regardless of gender, status, race, and color. It makes a tautua a good tautai and tufuga. As a tautai, he is like a fisherman who will go beyond the rough weather in search of fish for the family. As a tufuga, despite how high the mountains are, he will search for the best wood to build a strong house for his family. Thus, a tautua is someone who has the courage to face any challenge, such as breaking away from the spaces of norms and traditions he or she is familiar with, and entering new spaces where he or she is able to find ways to help fulfill his or her role as a person that belongs to a particular place. And this approach is revealed in the reciprocal value and practice of tautua. 
Tautuatoa as a category speaks of the action of undertaking service in-between people and spaces by the tautua whose places/spaces of belonging to a local context, and the various and different relationships he or she is linked to in that place are explored through the hermeneutical lenses of fa'asinomaga. Tautuatoa as the second category expresses the actions undertaken by a tautua in between those spaces and relationships. It is a relational treatment of each other with fa'aaloalo (respect), and loto fuatiaifo (subjectivity). Tautuatoa as action/s undertaken by a tautua inbetween spaces and relationships reflect a tautua's subjectivity to act in a way that will enable consideration of the needs of those whose needs should be given priority. Thus, Tautuaileva as action shows that the subjectivity of a tautua to respond to a situation that fulfills a need is important. It shows the creation of new ways to consider various and different needs of local people in accordance with the situations they are engaged in. Furthermore, it undertakes ways to break down social and cultural barriers that have been stumbling blocks to local people's fulfilling of their needs like the marginalized men and women.

\section{Interpretation of a Bible text (John 4:16-30) using the Samoan hermeneutic of Tautuaileva}

These questions from the Tautuaileva hermeneutic will guide the interpretation of John 4:16-30. First, does the language of the world encoded in the text tell and show Jesus and the Samaritan woman characters as servants in-between spaces - servants who have shown that they belong (fa'asinomaga) to the local space in the text in terms of their relationship to other people in that space? Does the language of the text tell and show Jesus and the Samaritan woman as courageous servants (tautuatoa)?

From Tautuaileva hermeneutic, I see in John 4:16-30 as a narrative unit, the roles and responsibilities of Jesus and the Samaritan woman characters as local tautua or servants carrying out their roles as such in between spaces. They have shown that they consider important the well-being of the local people of Samaria in this part of the story - the well-being of being included in Jesus' saving actions (Koester 1990: 665-680). For example, the conversation between Jesus and the woman in John 4:1-15 shows that Jesus understands that he as a Jew relates to the Samaritan people. His meeting the Samaritan woman at the well of Jacob depicts that relationship - the well that both the Jews and the Samaritans got water from when they were one nation. But, the long standing hatred between the Jews and Samaritans of each other did not stop Jesus from bringing the Samaritans into Salvation. Jesus is practicing serving his people (the people of Israel) by standing as a tautuaileva, a servant in between spaces - the space of the Jews and the space of the Samaritans. Jesus has proven himself a tautuatoa (courageous servant) who has taken the risks by crossing the line of the conflict between Jews and Samaritans to make sure that all the people of his Israel's family, God's chosen nation, are given the chance of salvation. It is the main reason why he goes through Samaria on his return from Jerusalem in this part of John's story of Jesus' ministry.

The Samaritan woman likewise from her status as a woman also stands in-between spaces of Jesus and her people, people of Samaria, in order to bring her people into drinking the water that Jesus offered her. The woman does this by leaving her water jar and went back to the city to bring her people to Jesus (vv. 28-30). The water jar she left behind is symbolically interpreted as the woman's old way of life - the life of having five husbands and another man not her husband. She comes out of that old life and enters the space of life worth living for as Jesus suggested - the living water. And the living water is repentance and returning to God wholeheartedly. The woman's response to Jesus' request makes her a courageous servant of Samaria. This is proven in the word

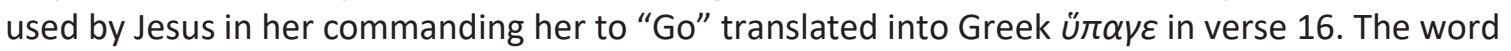
Ü $\pi \alpha \gamma \varepsilon$ meaning depart is an intransitive verb that "always expresses the past tense by the Imperfect" (Wenham 1965: 52-54, 103, 203). As such, it expresses the 'go' that Jesus commands that is for the woman to make her being the person that draws water from Jacob's well, as the person that is used here by God to bring her own people into God's salvation in and through Jesus Christ's ministry. Thus, her drawing water from the well where she met Jesus is the departure point for returning to her Samaritan households. In this way, it implies Jesus' expectation of this woman's 
drawing of water which is to return to serve her Samaritan household/s in light of what she has experienced and understood in her encounter with Jesus. Thus, the sending of this woman is a sending of a messenger or a disciple (a tautuatoa - courageous servant) to bring her people, the local people of Samaria to Jesus. This woman's obedience, to do Jesus' sending of her, makes her a local disciple, whose role is to look after the needs and rights of her people in this part of the story. Hence, this woman can be looked at as a disciple in this part of Jesus' ministry - which is in the local space and place of Samaria.

The interpretation using the Tautuaileva hermeneutic has shown Jesus as saviour entering spaces that expose danger to his life to save the long lost people of his family - the Samaritans. The interpretation also in the use of Tautuaileva hermeneutic has shown two aspects of the Samaritan woman as a tautuatoa (courageous servant) who has a very close sense of belonging to the local place of Samaria, and who stands in-between spaces as shown in the story, crossing local social and cultural boundaries as a woman, not only to help her but more importantly her people. First, she belongs to Samaria as a woman whose role is to get water from the well of Jacob. Second, regardless of her reputation as a woman and her role as woman in accordance with the life she encounters in local Samaria, this woman also belongs to Samaria as a person chosen by God to spread the word of salvation. Thus, her other sense of belonging to Samaria is as a good person who helps make her people become members of God's kingdom. Her work makes her a person with honour and her people as honoured people as well in God's kingdom.

\section{Conclusion}

In conclusion, Tautuaileva as a hermeneutic recognizes egalitarian issues such as gendering and elitism in contemporary Samoan world to be used as a reading approach to seek in the Bible text more understanding about egalitarianism. It depicts the consideration of the needs and rights of local people in a Samoan local family or community regardless of who they are - in terms of gender and status. And that consideration is the type of egalitarianism that I have described as not seeking equality among local people but recognition of each other with respect in accordance with each person's status in a local family or community. This is an approach that the Samoan government could have used in their attempt to change the Judiciary system of Samoa where the Land and Titles Court have its own High Court and Court of Final Appeal and Review. The use of the tautuaileva approach as an example was shown in the interpretation of the characters of Jesus and the Samaritan woman shown above. It is a social and cultural operation where, on the one hand, becoming a leader (as shown in Jesus' character) is not to oppress the people he or she leads but to serve them by caring for their needs. On the other hand, for the people in lower status (as shown in the character of the Samaritan woman), their being in such position is not to disrespect the leaders in their families and communities, but to serve their leaders by helping them find better ways to take care of their needs. According to my location of Tautuaileva, the leaders' failure to recognize those in need is approached not in an aggressive and violent way but in the Samoan way of amio fa'aaloalo (respectable behaviour) and loto maulalo (humility). In other words, Tautuaileva is not to create a revolutionary or subversive type of resistance against those in power. Rather, it is the beginning for those in need (poor, marginalized, women) to realize ways that would help them move away from the margin such as the Samaritan woman. One such way is found in taking advantage of the available understandings, resources, and opportunities he or she is able to have access to in his or her local world/s. The Samaritan woman takes advantage of the water resource offered by Jesus for her and for her people. It is about seeking survival in accordance with the reality of life a person in need is encountering. In other words, entering the third space of Tautuaileva involves weighing the opportunities available to them and then making a decision on the opportunity that would best fulfil a servant's, his or her family's and/or his or her household's needs. As mentioned above, the motivation of a family member as a tautua (either a male or female) to enter the third space of Tautuaileva is his or her realization of the need to seek in other spaces ways to help fulfil his or her family's needs. This type of tautua is a place-based mission to be carried out in relation to the many changes occurring in a particular local 
community. The use of a hermeneutical critical approach that considers the world of a reader now in reading the Bible as shown in this article, is a new approach to reading the Bible. Its use as emphasized in this study is to raise questions as critical elements to guide a reading of a text. Thus, the basis of the interpretation is the text not the reader.

\section{References}

Ashcroft, B., Griffiths, G., and Tiffin, H. 2000. Post-colonial studies: The key concepts. Routledge, London.

Bhabha, H.K. 1994. The location of culture. Routledge, London; New York.

Brown, L. 1993. The new shorter Oxford English dictionary: The new authority of English language. Oxford: Claredon.

Choi, N. 2010. "Egalitarianism." Pp. 411-414 in Encyclopedia of political theory, ed M. Bevir. SAGE Publications, Inc., Thousand Oaks: California. doi: 10.4135/9781412958660.n137.

Duling, D. C. 2011. A Marginal Scribe: Studies in the Gospel of Matthew in a Social-Scientific Perspective (Matrix: The Bible in Mediterranean Context. Cascade Books, Eugene: Oregon.

Essenburg, M. 1992. "Egalitarianism," Pp. 128-129 in Encyclopedia of Biblical and Christian Ethics, ed R. K. Harrison. Thomas Nelson Publishers, Edinburg.

Habermas, J. 1985. "Hermeneutics and the Social Sciences." Pp. 293-294 in The Hermeneutics Reader, ed. K. Mueller-Vollmer. The Continuum Publishing Company, New York.

Jasper, D. 2004. A Short Introduction to Hermeneutics. Westminster John Knox Press, Louisville: Kentucky.

Kent, S. 1999. "Egalitarianism, equality, and equitable power." Pp. 37 in Manifesting power: Gender and interpretation of power in archaeology, ed. T. L. Sweely. London: Routledge.

Koester, C. R. 1990. "The Savior of the World" (John 4:42)." Journal of Biblical Literature 109: 665680.

Le Tagaloa, F. 1997. O le Faasinomaga: Le Tagata ma lona Faasinomaga. Lamepa Press, Alafua: Western Samoa.

Lundin, R., Thiselton, A. C., Walhout, C. 1985. The Responsibility of Hermeneutics. W. B. Eerdmans, Grand Rapids: Michigan.

Mailo, M. 2016. Bible-ing My Samoan: Native Languages and the Politics of Bible Translating in the 19th Century. Piula Publications, Apia: Samoa.

Meleisea, M. 1987. Lagaga: A Short History of Western Samoa. University of the South Pacific, Suva: Fiji.

Milner, G. B. 1966. Samoan Dictionary: Samoan-English, English-Samoan. Oxford University Press, London.

Nofoaiga, V. 2017. A Samoan Reading of Discipleship in Matthew. Society of Biblical Literature Press, Atlanta: Georgia.

Nofoaiga, V. 2018. "Jesus the Fiaola (Opportunity Seeker): A Postcolonial Samoan Reading of Matthew 7:24-8:22." Pp. 163-178 in Sea of Readings: The Bible in the South Pacific, ed. J. Havea. Society of Biblical Literature Press, Atlanta: Georgia.

Roth, J. K. 1995. International Encyclopedia of Ethics. Fitzroy Dearborn Publishers, London.

Schoeffel, P. 1995. "The Samoan Concept of Feagaiga and its Transformation." Pp 85-105 in Tonga and Samoa: Images of Gender and Polity, ed. J. Huntsman. Macmillan Brown Centre for Pacific Studies, Christchurch: New Zealand.

Tamasese Ta'isi Efi, T. 2008. "Religion, law and the Samoan indigenous reference." Keynote address for Pacific futures law and religion symposium, National University of Samoa, Lepapaigalagala, Samoa 3 December. http://www.head-of-state-samoa.ws/pages/welcome.html (accessed on 14th July 2013).

Taylor, C. 1985. Philosophy and the Human Sciences: Philosophical Papers 2. Cambridge University Press, Cambridge. 
Thiselton, A. C. 1980. The Two Horizons: New Testament Hermeneutical and Philosophical Description with special reference to Heidegger, Bultmann, Gadamer and Wittgenstein. The Paternoster Press, Exeter.

Tofaeono, A. 2000. Eco-Theology: Aiga-The Household of Life - A Perspective from Living Myths and Traditions of Samoa. World Mission Script 7.Erlangen: Erlanger Verlag für Mission Und Okumene.

Wainwright, E.M. 1991. Towards a Feminist Critical Reading of the Gospel according to Matthew. Volume 60 of Beihefte zur Zeitschrift für die neutestamentliche Wissenschaft, Walter De Gruyter \& Co., Berlin: Germany.

Warnke, G. 1987. Gadamer: Hermeneutics, Tradition and Reason. Stanford University Press, Stanford: California.

Wenham, J. W. 1965. The Elements of the New Testament Greek. Cambridge University Press, Cambridge: England. 